\title{
2'-OMe-Uridin-3'-yl (3',5')-5'-O-(2'-OMe-cytidine)- methanephosphonothioates - new building blocks for synthesis of chimeric oligonucleotides
}

\author{
Lucyna A. Wozniak*a, Wiesław Majzner ${ }^{b}$, and Wojciech J. Stec ${ }^{\text {a }}$ \\ ${ }^{a}$ Centre of Molecular and Macromolecular Studies, Polish Academy of Sciences, Department of \\ Bioorganic Chemistry, 112 Sienkiewicza Str., 90-363 Lodz, Poland, ${ }^{b}$ Institute of General Food \\ Chemistry, Technical University of Lodz, Stefanowskiego 4/10, 90-924 Lodz, Poland \\ E-mail: lawozn@bio.cbmm.lodz.pl
}

\section{Dedicated to Professor Mieczysław Mąkosza on the occasion of his $\mathbf{7 0}^{\text {th }}$ birthday}

(received 29 Oct 03; accepted 09 Jan 04; published on the web 13 Jan 04)

\begin{abstract}
The efficient one-pot synthesis and X-ray analysis of the molecular structure of the SLOWeluting diastereomer of 5'-OH-2'-OMe-uridin-3'-yl (3',5')-5'-O-( $N$-isobutyryl 2'-OMe-cytidine) methanephosphonothioate is reported. The $R_{\mathrm{P}}$-absolute configuration of the $P$-chiral centre is unambiguously determined and structural parameters of the molecule are discussed.
\end{abstract}

Keywords: Dinucleoside methanephosphonothioate, $\mathrm{X}$ ray, absolute configuration, chimeric oligonucleotides, dimeric building blocks

\section{Introduction}

Chimeric oligonucleotide (1) constructs containing $P$-achiral internucleotide phosphodiester function selectively replaced by a $P$-chiral methanephosphonate 3',O-5',O-linkage have proved to be excellent tools for sequence specific controlled RNA disfunction due to enhanced cellular uptake, resistance to nucleases, high avidity towards RNA sequences, and blocking of transcription process independent of RNAse H. ${ }^{1,2,3}$.

In spite of these advantages, the practical application of these constructs to antisense therapy is hampered by difficulties in efficient synthesis of $R_{\mathrm{P}}$-dinucleoside (3',5')-methanephosphonates $(2)^{4}$ used as building blocks for production of $\mathbf{1}$. In our approach to a stereoconvergent synthesis of 2 we evaluated a methodology based upon the synthesis of nucleoside 3'-Omethanephosphonanilidothioates, their separation into diastereomers, and stereospecific conversion of each diastereomer into nucleoside $3^{\prime}-O$-(S-alkyl methanephoshonothiolates $){ }^{5}$ These are convenient substrates for the one step synthesis of $R_{\mathrm{P}}-\mathbf{2}$. 


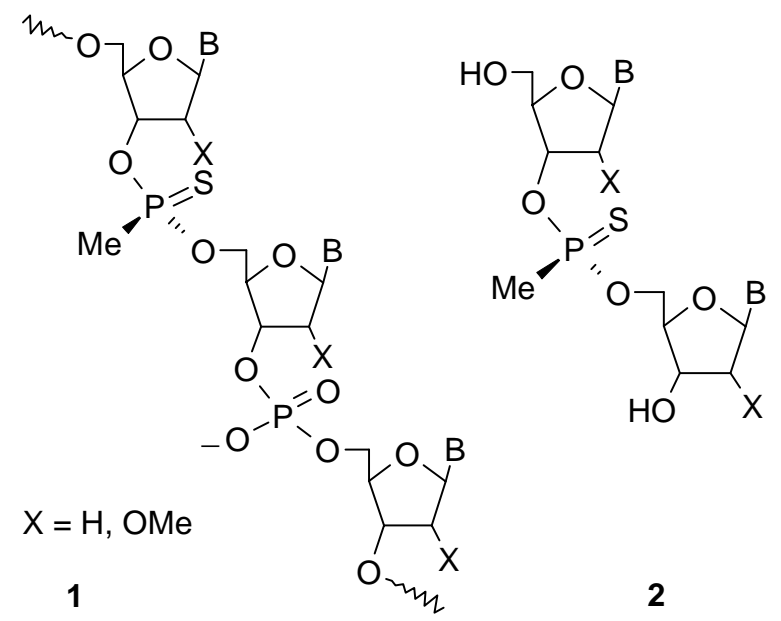

Our new approach to the efficient synthesis of $\mathbf{2}$ involves a synthesis of dinucleoside (3',5')methanephosphonothioates (3), their separation into diastereomers, and stereoconvergent oxidation of both stereoisomers into the desired $R_{\mathrm{p}}-\mathbf{2}$. Studies on the last step of methodology are in progress. However, having separated isomers $\mathbf{3}$ in our hands, we were tempted to incorporate them into oligonucleotide chains and study the properties of the chimeric constructs analogous to 1. By this means methanephosphonothioate dimers 3 of known absolute configuration at phosphorus could be incorporated. ${ }^{6}$ The unambiguous assignment of the absolute configuration at phosphorus in both diastereomers of $\mathbf{3}$ is indispensable for these studies.

Here we describe a one-pot synthesis of dimers 3, and their separation into SLOW and $\mathrm{FAST}^{7}$ eluted diastereomers, crystallization of isomer SLOW-4, and its X-ray analysis resulting in assignment of an absolute configuration at the phosphorus atom. Previously only few crystal structures of di(2'-deoxynucleoside) methanephosphonates have been solved by X-ray diffraction analysis, namely $S_{\mathrm{P}-\mathrm{dA}} \mathrm{P}_{\mathrm{PMe}} \mathrm{T},{ }^{8}{ }_{\mathrm{P}}-\mathrm{dC}_{\mathrm{PMe}} \mathrm{G},{ }^{9}$ and $S_{\mathrm{P}}-4$-thioT $\mathrm{PMe}_{\mathrm{PMe}} \mathrm{T}$ with modified 4thiothymine. ${ }^{10}$

\section{Results and Discussion}

The possibility of the use of bifunctional $\mathrm{P}^{\mathrm{III}}$ phosphitylating agents other than methyldichlorophosphine ${ }^{11,12}$ for a large scale synthesis of dinucleotides was appealing, since it is known that $\mathrm{MePCl}_{2}$ is highly reactive and therefore not a selective reagent. This causes serious problems, particularly when large-scale protocols are evaluated. In the case of the synthesis of $\left(3^{\prime}, 5^{\prime}\right)$-dinucleotides, the formation of symmetrical by-products, namely (3',3')-dinucleotides and $\left(5^{\prime}, 5^{\prime}\right)$-dinucleotides, not only decreases the yield of the required product but also complicates purification procedures. In contrast, the use of bifunctional $\mathrm{P}^{\mathrm{V}}$ phosphitylating reagents is often limited by a lower reactivity of these reagents and the demand for specific catalysts and/or activators. ${ }^{13}$ 
The approach reported here is based upon our observation that in situ reaction of $\mathrm{MePCl}_{2}$ with 1,2,4-triazole in the presence of amine generated a phosphitylating reagent highly reactive under mild conditions, but selective towards 3'-OH and 5'-OH groups of the properly protected nucleosides.

1,2,4-Triazole has been widely used for the activation of phosphodichloridates ${ }^{14}$ and phosphodichloridites ${ }^{15}$ under various reaction conditions. These include $H$-phosphonate and phosphotriester syntheses. In the $H$-phosphonate approach ${ }^{16}$ and its numerous modifications, 2cyanoethyl nucleoside 3'-phosphonates have been used as monomers, ${ }^{17}$ obtained by phosphitylation of nucleosides with a phosphorus trichloride-imidazole reagent ${ }^{18}$ or $\beta$ cyanoethyl phosphoro-bis(1,2,4-triazolidite). ${ }^{19}$ Triazolomonoesters, prepared from bis(1,2,4triazolide) trifluoromethylphosphinic acid were used in reaction with protected nucleosides, and the resulting triazolomonoesters of nucleosides were efficiently hydrolyzed to $H$-phosphonates, and oxidized to give trifluoromethylphosphonate monoesters. ${ }^{20}$ Analogously, $H$ phosphonothioates were obtained when $\mathrm{H}_{2} \mathrm{~S}$ was used instead of water to hydrolyze the intermediary triazolidites. ${ }^{21,22}$ Fourrey et al. used 1,2,4-triazole and $1 H$-tetrazole to increase selectivity of phosphitylation in oligonucleotides synthesis via the phosphite triesters. ${ }^{23}$ Wenzel et al. elaborated efficient synthesis of disaccharide analogs via the phosphate triester approach, including subsequent phosphitylation of properly protected glucopyranoses with 1,1,1-trichloro2-methylprop-2-yl dichlorophosphite/1,2,4-triazole, followed by oxidation of the formed phosphite under anhydrous conditions. ${ }^{24}$

In the studies reported here, synthesis of dinucleotides 3 was performed as one-pot reaction, without isolation of either the phosphitylating agent or the corresponding phosphitylated intermediates.

The 5'-DMT-protected nucleoside 6 was added dropwise into methanephoshono-bis(1,2,4triazolidite) (5) generated at $0{ }^{\circ} \mathrm{C}\left[{ }^{31} \mathrm{P}\right.$ NMR: $\delta 73.47 \mathrm{ppm} ;{ }^{1} \mathrm{H}$ NMR: 2.25 (d, 3H, $\left.{ }^{2} J_{\mathrm{PH}}=15.6 \mathrm{~Hz}\right)$, $8.15,9.05]$. After 45 min the 3'-O-protected nucleoside 7 dissolved in THF was added in one portion and stirring continued for further $1.5 \mathrm{~h}$ at room temperature. Elemental sulfur (2-3 fold molar excess) was added, and the reaction mixture was left overnight at room temperature. The expected dimer $8\left({ }^{31} \mathrm{P}\right.$ NMR $\left.\delta: 100.16,98.29 \mathrm{ppm}\right)$ was formed as a mixture of diastereomers in approx. $85 \%$ yield (in 1:2 ratio as estimated from ${ }^{31} \mathrm{P}$ NMR spectrum of a crude reaction mixture). Without purification, fully protected dimer 8 was treated with triethylamine trishydrofluoride to remove 3'-O-tertbutyldimethylsilyl protecting group. Partially deprotected dinucleoside $\left(3^{\prime}, 5^{\prime}\right)$-methanephosphonothioates $\mathbf{3}$ were separated into diastereomers via a silica gel column chromatography. It was found that separation of diastereomers $\mathbf{8}$ is much less efficient than separation of partially deprotected dimers 3, and column chromatography purification is not required after synthesis of fully protected dinucleotides $\mathbf{8}$. 


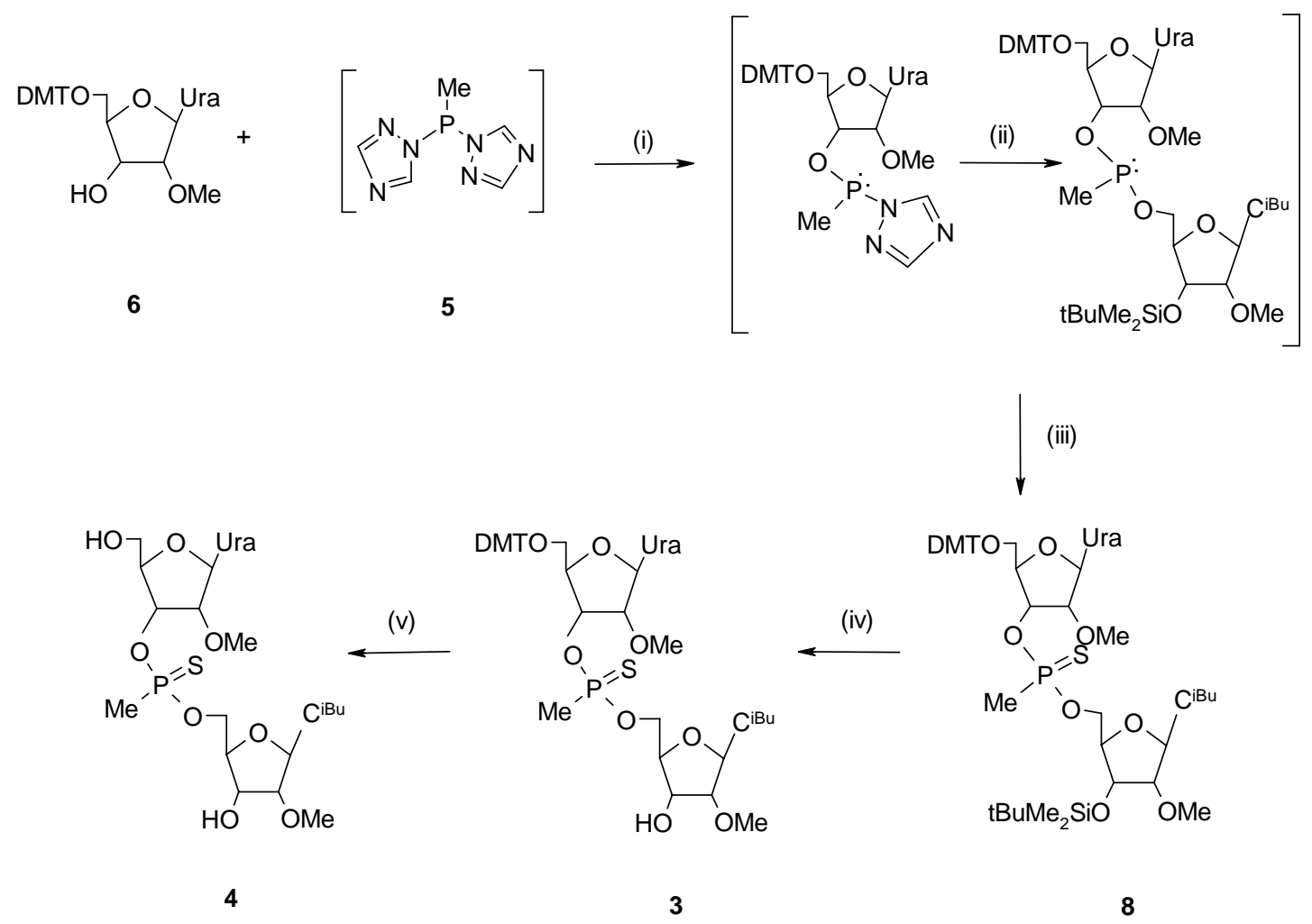

Scheme 1. Reagents and reaction conditions: (i) dropwise addition of 6 to 5, ice bath, 45 min; (ii) protected cytidine 7 in THF, room temp, $1.5 \mathrm{~h}$; (iii) elemental sulfur, RT, overnight, followed by aqueous work-up, precipitation; (iv) $\mathrm{Et}_{3} \mathrm{~N} \cdot 3 \mathrm{HF} / \mathrm{Et}_{3} \mathrm{~N}$ in $\mathrm{THF}$, followed by a silica gel column chromatography; (v) $2 \%$ DCA in $\mathrm{CH}_{2} \mathrm{Cl}_{2}, 10$ min.

The major advantage of the approach presented is that the formation of symmetrical by products such as $\left(3^{\prime}, 3^{\prime}\right)$-dinucleotides or $\left(5^{\prime}, 5^{\prime}\right)$-dinucleotides is eliminated. In the case of condensation by means of $\mathrm{MePCl}_{2}$, these by-products are always present, and efforts in our group as well as in others have been only partially successful in reducing their formation, even when the reaction was performed at low temperatures. ${ }^{25}$

Diastereomeric compounds 3 after 3'-O-deprotection afforded FAST-eluted and SLOWeluted diastereomers 3 , which under treatment with dichloroacetic acid were converted into HOdeprotected diastereomers FAST-4 and SLOW-4, respectively. 


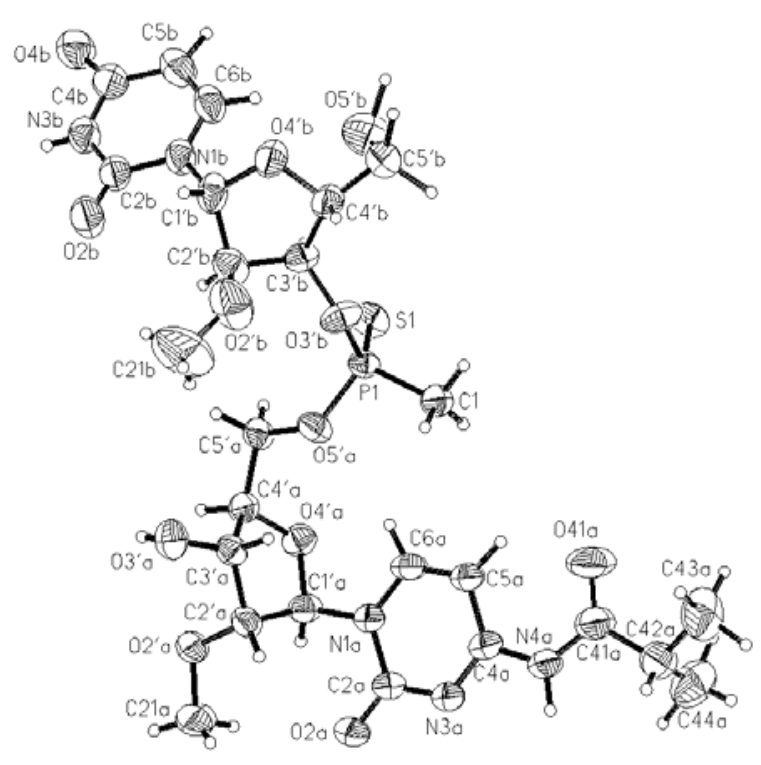

$\mathbf{a}$

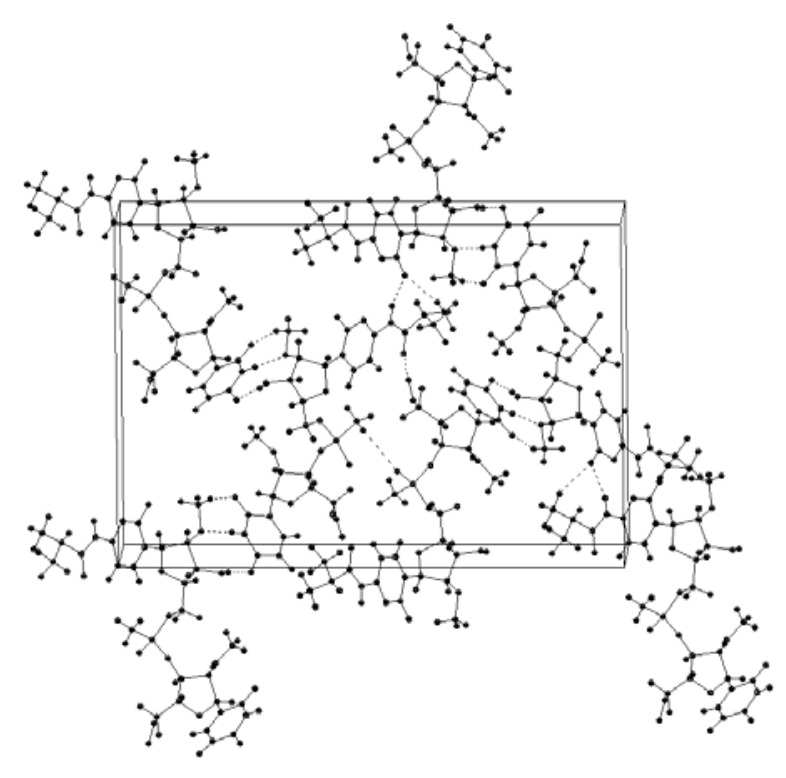

b

Figure 1. The ORTEP drawing with the numbering scheme of SLOW-4 in the crystal (displacement ellipsoids drawn with $50 \%$ probability level) (a), and molecular packing in the crystal cell (b). Selected bond lengths $[\AA]$, angles and torsion angles [ $\left.{ }^{\circ}\right]: \mathrm{P}_{1}-\mathrm{S}_{1} 1.9159(2), \mathrm{P}_{1}-\mathrm{C}_{1}$ 1.778(4), $\mathrm{P}_{1}-\mathrm{O}_{3}$ ' 1.516(6), $\mathrm{C}_{1}{ }^{\prime} \mathrm{e}_{1 \mathrm{~b}} 1.483(5), \mathrm{C}_{2}{ }^{\prime} \mathrm{a}^{-} \mathrm{C}_{3}{ }^{\prime} \mathrm{a} 1.532(5), \mathrm{C}_{2}{ }^{\prime} \mathrm{b}-\mathrm{C}_{3}{ }^{\prime} \mathrm{b} 1.520(5), \mathrm{O}_{2}{ }^{\prime} \mathrm{a}-\mathrm{C}_{21 \mathrm{a}}$ 1.441(5), $\mathrm{O}_{2}{ }^{\prime} \mathrm{a}-\mathrm{C}_{21 \mathrm{a}}$ 1.361(8); $\mathrm{C}_{1}-\mathrm{P}_{1}-\mathrm{S}_{1}$ 118.01(1), $\mathrm{O}_{5}{ }^{\prime} \mathrm{a}_{1}-\mathrm{C}_{1}$ 101.28(2), $\mathrm{O}_{5}{ }^{\prime} \mathrm{a}-\mathrm{P}_{1}-\mathrm{S}_{1}$ 114.48(1), $\mathrm{C}_{5}{ }^{\prime}{ }^{-} \mathrm{O}_{5}{ }^{\prime}{ }-\mathrm{P}_{1} 123.5(2)$, $\mathrm{O}_{3{ }^{\prime} \mathrm{b}}-\mathrm{P}_{1}-\mathrm{O}_{5^{\prime} \mathrm{a}}$ 105.10(1), $\mathrm{O}_{3^{\prime} \mathrm{b}}-\mathrm{P}_{1}-\mathrm{C}_{1}$ 100.8(2), $\mathrm{O}_{3^{\prime} \mathrm{b}}-\mathrm{P}_{1}-\mathrm{S}_{1}$ 115.14(1), $\mathrm{C}_{3^{\prime} \mathrm{b}}-\mathrm{O}_{3^{\prime} \mathrm{b}} \mathrm{-}-\mathrm{P}_{1}$ 124.3(2), $\mathrm{S}_{1}-\mathrm{P}_{1^{-}}$

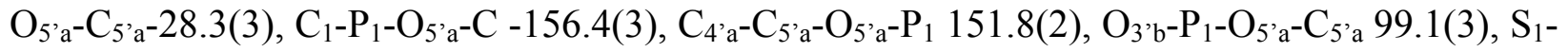

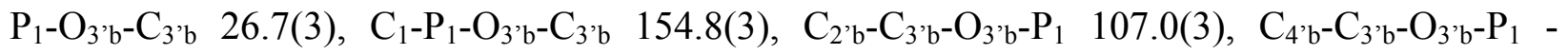
138.4(3), $\mathrm{O}_{5}{ }^{\prime} \mathrm{a}-\mathrm{P}_{1}-\mathrm{O}_{3}{ }^{\prime} \mathrm{b}-\mathrm{C}_{3}{ }^{\prime} \mathrm{b}-100.3(3)$.

Isomer SLOW-4 obtained from SLOW-3, was crystallized from 95\% ethanol giving crystals suitable for X-ray diffraction analysis. Single crystal data for SLOW-4 were collected at $293 \mathrm{~K}$. The absolute structure was determined by the Flack method with result $\chi=-0.02(2) .{ }^{26}$ It was found that the asymmetric unit consists of four molecules of SLOW-4 without solvent (Figure $1 b)$.

Atomic distances and angles both for uridyl (Ura) and $N$-isobutyryl cytidyl (Cyt) moieties are not significantly changed compared to data for the analogous unprotected and unmodified nucleotides. ${ }^{27}$ The six atoms of both pyrimidine rings are almost co-planar, with bond lengths and angles within the average range published for $2^{\prime}$-OMe ribonucleotides. ${ }^{28,29,30}$ 
Table 1. Crystal data and experimental details for SLOW-4

\begin{tabular}{|c|c|c|}
\hline \multicolumn{2}{|c|}{ Molecular formula } & $\mathrm{C}_{25} \mathrm{H}_{36} \mathrm{~N}_{5} \mathrm{O}_{12} \mathrm{PS}$ \\
\hline \multicolumn{2}{|c|}{ Formula weight } & 661.62 \\
\hline \multicolumn{2}{|c|}{ Crystallographic system } & orthorhombic \\
\hline \multicolumn{2}{|c|}{ Space group } & $\mathrm{P} 2{ }_{1} 2_{1} 2_{1}$ \\
\hline \multicolumn{2}{|l|}{$\mathrm{a}(\AA)$} & $5.813(6)$ \\
\hline \multicolumn{2}{|l|}{$\mathrm{b}(\AA)$} & $18.949(3)$ \\
\hline \multicolumn{2}{|l|}{$\mathrm{c}(\AA)$} & $28.190(5)$ \\
\hline \multicolumn{2}{|l|}{$\mathrm{V}\left(\AA^{3}\right)$} & $3105.0(30)$ \\
\hline \multicolumn{2}{|l|}{ Z } & 4 \\
\hline \multicolumn{2}{|l|}{$D_{C}\left(g / \mathrm{cm}^{3}\right)$} & 1.415 \\
\hline \multicolumn{2}{|l|}{$\mu\left[\mathrm{cm}^{-1}\right]$} & 20.14 \\
\hline \multicolumn{2}{|c|}{ Crystal dimensions (mm) } & $0.06 \times 0.08 \times 1.40$ \\
\hline \multicolumn{2}{|c|}{ Maximum $2 \theta\left(^{\circ}\right)$} & 150 \\
\hline \multicolumn{2}{|c|}{ Radiation, $\lambda(\AA)$} & $\mathrm{CuK} \alpha, 1.54184$ \\
\hline \multicolumn{2}{|c|}{ Scan mode } & $\omega / 2 \theta$ \\
\hline \multicolumn{2}{|l|}{ Scan width $\left({ }^{\circ}\right)$} & $1.20+0.14 \tan \theta$ \\
\hline \multicolumn{2}{|l|}{$h k l$ ranges: $h=$} & $\begin{array}{ll}0 & 7\end{array}$ \\
\hline \multicolumn{2}{|l|}{$k=$} & $0 \quad 23$ \\
\hline \multicolumn{2}{|l|}{$l=$} & $-35 \quad 35$ \\
\hline \multirow[t]{3}{*}{ EAC correction: } & $\min :$ & 0.9814 \\
\hline & $\max :$ & 0.9996 \\
\hline & ave: & 0.9889 \\
\hline No. of reflections: & unique & 6383 \\
\hline \multicolumn{2}{|c|}{ refine with $I>0 \sigma(I)$} & 6010 \\
\hline \multicolumn{2}{|c|}{ observed with $I>2 \sigma(I)$} & 5304 \\
\hline \multicolumn{2}{|c|}{ No. of parameters refined } & 530 \\
\hline \multicolumn{2}{|c|}{ No. of restraints } & 1 \\
\hline \multicolumn{2}{|c|}{ Largest diff. peak $\left(\mathrm{e} \AA^{-3}\right)$} & 0.262 \\
\hline \multicolumn{2}{|c|}{ Largest diff. hole $\left(\mathrm{e} \AA^{-3}\right)$} & -0.539 \\
\hline \multicolumn{2}{|c|}{$R_{\mathrm{obs}}$} & 0.0490 \\
\hline$w R_{\mathrm{obs}}$ & & 0.1297 \\
\hline weighting coeff." & $\mathrm{m}$ & 0.0834 \\
\hline & $\mathrm{n}$ & 0.5525 \\
\hline extinction coeff. ${ }^{* *}$ & $\mathrm{k}$ & $0.0005(2)$ \\
\hline $\mathrm{S}_{\mathrm{obs}}$ & & 1.079 \\
\hline shift/esd max & & 0.000 \\
\hline $\mathrm{R}_{\text {int }}$ & & 0.0469 \\
\hline $\mathrm{T}_{\text {meas. }}$ & & $293(2)$ \\
\hline $\mathrm{F}(000)$ & & 1392 \\
\hline
\end{tabular}


Table 1. Continued

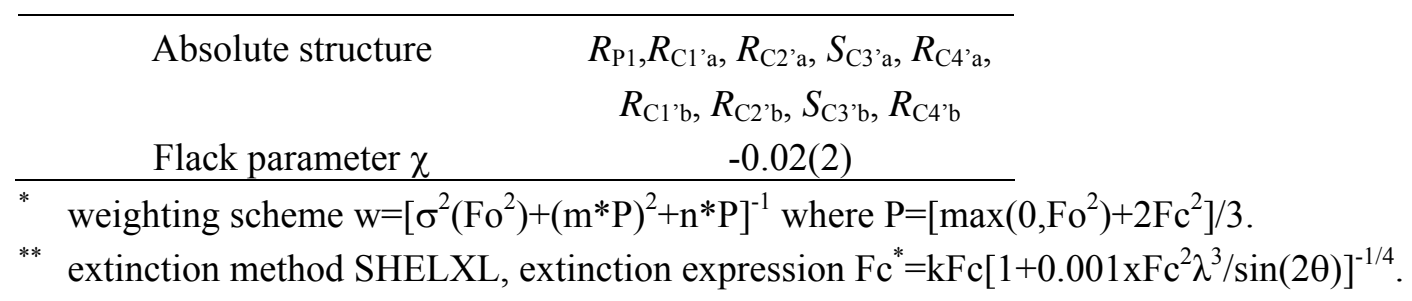

Table 2. Endocyclic torsion angles and pseudorotation parameters of 2'-OMe ribofuranosyl moieties of $R_{\mathrm{P}}-4$ and torsion angles of the methanephosphonothioate-sugar bond

\begin{tabular}{|c|c|c|c|c|c|c|}
\hline Torsion angle & Design. & $\mathrm{U}_{2}$ '-OMe & $\mathrm{C}_{2}{ }^{\prime}-\mathrm{OMe}$ & Torsion angle & Design. & $R_{\mathrm{P}}-4$ \\
\hline $\mathrm{C}_{4},-\mathrm{O}_{4},-\mathrm{C}_{1},-\mathrm{C}_{2}$, & $v_{0}$ & 3.7 & 7.1 & $\mathrm{O}_{3},-\mathrm{P}_{-} \mathrm{O}_{5}, \mathrm{a}^{-} \mathrm{C}_{5}$, & $\alpha$ & 99.1 \\
\hline $\mathrm{O}_{4},-\mathrm{C}_{1},-\mathrm{C}_{2},-\mathrm{C}_{3}$, & $v_{1}$ & -26.0 & -28.1 & $\mathrm{O}_{4}, \mathrm{a}-\mathrm{C}_{5}, \mathrm{a}-\mathrm{O}_{5}, \mathrm{a}-\mathrm{P}$ & $\beta$ & 151.8 \\
\hline $\mathrm{C}_{1},-\mathrm{C}_{2},-\mathrm{C}_{3},-\mathrm{C}_{4}$ & $v_{2}$ & 37.3 & 37.7 & $\mathrm{C}_{3},{ }^{\prime}-\mathrm{C}_{4},{ }^{\prime}-\mathrm{C}_{5},{ }_{\mathrm{a}}-\mathrm{O}_{5}$ & $\gamma$ & 57.1 \\
\hline $\mathrm{C}_{2},-\mathrm{C}_{3},-\mathrm{C}_{4},-\mathrm{O}_{4}$ & $v_{3}$ & -36.3 & -34.3 & $\mathrm{O}_{3},{ }_{\mathrm{a}}-\mathrm{C}_{3}{ }^{\prime} \mathrm{a}^{-}-\mathrm{C}_{4}{ }^{\prime} \mathrm{a}-\mathrm{C}_{5}{ }^{\prime} \mathrm{a}$ & $\delta$ & 73.2 \\
\hline $\mathrm{C}_{3},-\mathrm{C}_{4},-\mathrm{O}_{4},-\mathrm{C}_{1}$ & $v_{4}$ & 20.7 & 17.2 & $\mathrm{C}_{4}{ }^{\prime} \mathrm{b}^{-}-\mathrm{C}_{3},-\mathrm{O}_{3}{ }^{\prime} \mathrm{b}-\mathrm{P}$ & $\varepsilon$ & -138.4 \\
\hline Phase angle & $P$ & $8^{\circ}$ & $13.4^{\circ}$ & $\mathrm{O}_{5}{ }^{\prime} \mathrm{a}-\mathrm{P}-\mathrm{O}_{3}{ }^{\prime} \mathrm{b}-\mathrm{C}_{3}{ }^{\prime} \mathrm{b}$ & $\zeta$ & -100.3 \\
\hline Ring puckering & $\psi$ & ${ }^{3} \mathrm{E}$ & ${ }^{3} \mathrm{E}$ & & & \\
\hline
\end{tabular}

${ }^{a} \tan P=\left(v_{4}+v_{1}\right)-\left(v_{3}+v_{0}\right) / 2 v_{2}\left(\sin 36^{\circ}+\sin 72^{\circ}\right)$.

From analysis of the calculated torsion angles (Table 2) it could be concluded that the uridyl $\mathrm{U}_{2}$,-OMe ribose adopts a clear $\mathrm{C}_{3}$,-endo pucker with $\mathrm{C}_{3}$, displaced from the plane defined by $\mathrm{C}_{1}, \mathrm{C}_{2}, \mathrm{C}_{4}$, and $\mathrm{O}_{4}$, atoms by $0.588 \AA$. The cytidyl $\mathrm{C}_{2}$ '-OMe ribose ring is puckered in envelope (E) form, with displacement from the plane by $0.214 \AA$. Therefore, furanose puckering, as determined for both nucleosides on the basis of pseudorotation phase angles $P$, indicates that both sugars are locked in the 3 '-endo conformation, a prerequisite of any RNA mimic. ${ }^{31}$ Both bases adopt anti- orientation about the glycosyl bond with additional intramolecular hydrogen contacts $\mathrm{C}_{1},(\mathrm{H}){ }^{\cdots} \mathrm{O}_{2}(2.43 \AA), \mathrm{O}_{4}, \cdots \mathrm{C}_{6}(\mathrm{H})(2.24 \AA)$ and $\mathrm{O}_{5}{ }^{\prime}{ }^{-} \mathrm{C}_{3}$ 'a $(2.5 \AA)$, stabilizing cytosine orientation. The 2'-methoxy groups of uridine and cytidine, with $\mathrm{O}_{2},-\mathrm{C}_{21}$ (methyl carbon) bonds are oriented antiperiplanar relative to $\mathrm{C}_{2},-\mathrm{C}_{3}$, bonds. The $\mathrm{C}_{3},-\mathrm{C}_{2},-\mathrm{O}_{2},-\mathrm{C}_{21}$ torsion angles are $165.6^{\circ}$ for (Ura), and $-139.3^{\circ}$ for $(\mathrm{Cyt}$ ), respectively. The methoxy group adopt an anti arrangement with respect to the ribose moieties, leading to an approximate trans orientation of $\mathrm{O}_{2}$,-C and $\mathrm{C}_{2},-\mathrm{C}_{3}$, bonds. However, the arrangement of methoxy group of uridine is partly restricted by the presence of the neighbouring cytidine. This methoxy group is in van der Waals contacts with atoms of cytosine as well as with $\mathrm{O}_{4}$, oxygen of furanose (at a distance of $2.23 \AA$ from $\mathrm{O}_{4}$ ). The observed conformational preferences of the $\mathrm{C}_{2}$ '-OMe moieties confirm that both sugar moieties $(+\mathrm{sc},+\mathrm{sc})$ are governed by the gauche effect.

The assigned absolute configuration at the methanephosphonothioate centre is $R_{\mathrm{P}}$. The P-O distances involving oxygen atoms $\mathrm{P}_{-} \mathrm{O}_{3},[1.590(2) \AA]$ and $\mathrm{P}_{-} \mathrm{O}_{5},[1.596(2) \AA]$ are of standard length as measured previously for unmodified oligonucleotides. ${ }^{32}$ The $\mathrm{P}-\mathrm{CH}_{3}$ bond distance is 
$1.78 \AA$ and is comparable with data previously obtained for internucleotide modified methanephosphonates. ${ }^{9}$ The length of the P-S bond $[\mathrm{P}-\mathrm{S}=1.915(9) \AA]$ could be compared with the PS bond in triester phosphorothionates, ${ }^{33}$ and is characteristic for a standard double $\mathrm{P}=\mathrm{S}$ bond.

The bond angles around phosphorus atom deviate somewhat from tetrahedral values. Somewhat low values were found for angles between oxygen atoms and the methyl group carbon $\left(\mathrm{O}_{5}{ }^{\prime}{ }_{a}-\mathrm{P}_{1}-\mathrm{C}_{1}=101.3^{\circ}\right.$ and $\left.\mathrm{O}_{3}{ }^{\prime} \mathrm{b}-\mathrm{P}_{1}-\mathrm{C}_{1}=100.8^{\circ}\right)$, whereas bond angles to sulfur are bigger and of comparable value for both the $3^{\prime}$ - and $5^{\prime}$ - directed bonds $\left(115.2^{\circ}\right.$ and $114.5^{\circ}$, respectively), analogously to geometry previously reported for deoxyadenylyl-3'-methanephosphonate-5'thymidine, ${ }^{8}$ and $S_{\mathrm{P}}$-thymidin-3-yl 4-thiothymidin-5-yl methanephosphonate. ${ }^{10}$

In conclusion, we have demonstrated that dinucleoside $\left(3^{\prime}, 5^{\prime}\right)$-methanephosphonothioates 3 can easily be prepared in a one pot reaction using in situ generated selective bifunctional phosphitylating reagent, namely methanephoshono-bis(1,2,4-triazolidite). Their chromatographic separation into diastereomerically pure isomers $\mathbf{3}$ can be efficiently achieved, as long as the removal of the 3'-O-protecting group precedes chromatographic separation. X-Ray analysis of SLOW-4 unambiguously assigned the absolute configuration as $R_{\mathrm{P}}$ for the isomer slowly eluted during chromatographic separation under normal phase conditions. It also confirmed 3'-endo conformation of the crystalline dimer $R_{\mathrm{P}}-\mathbf{4}$ and created a convenient basis for analysis of the behaviour of this molecule when incorporated into chimeric oligomers.

\section{Experimental Section}

General Procedures. Reactions were carried out under positive pressure of dry argon. Solvents and reagents were purified according to standard laboratory techniques and distilled directly into reaction vessels. Column chromatography and TLC analyses were performed on a silica gel (Kieselgel 60, 240-400 mesh, E.Merck Inc.), and silica gel HP TLC precoated $\mathrm{F}_{254}$ plates (purchased from E.Merck Inc.), respectively. NMR spectra were recorded on a Bruker Advance DRX 500 spectrometer, operating at $500.13 \mathrm{MHz}\left({ }^{1} \mathrm{H}\right)$, and $202.46 \mathrm{MHz}\left({ }^{31} \mathrm{P}\right)$. Chemical shifts

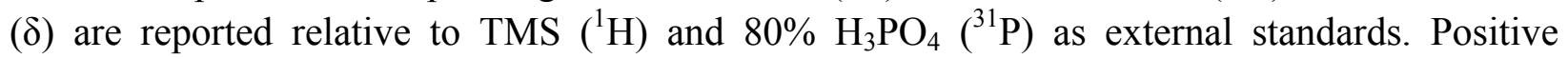
chemical shift values were assigned for compounds resonating at lower fields than standards. Mass spectra were recorded on a Finnigan Mat 95 (NBA, $\mathrm{Cs}^{+}$gun operating at $\left.13 \mathrm{keV}\right)$.

\section{Synthesis of $\left(R_{P}\right)$ and $\left(S_{P}\right) 5^{\prime}-O$-DMT-2'-OMe-uridin-3'-yl (3',5')-3'-O-(N-isobutyryl $2^{\prime}-$ OMe cytidine) 3'-methanephosphonothioates (3)}

A solution of 1,2,4-triazole (2.5 equiv) and triethylamine ( 3 equiv) in dry THF was cooled in an ice bath, and methyldichlorophosphine (1.1 equiv) was added with vigor ous stirring. After 20-25 min a solution of 5'-O-DMT 2'-OMe-uridine (6) (1 equiv) in THF was added dropwise at $0^{\circ} \mathrm{C}$. Stirring was continued for $45 \mathrm{~min}$, followed by addition of 3'-O-t-butyldimethylsilyl $N^{4}$ isobutyryl 2'-OMe-cytidine (7) in THF. Reaction mixture was warmed up to room temperature, stirred for additional $1.5 \mathrm{~h}$, and sulfur (2-fold molar excess) was added to this reaction mixture in 
one portion. Stirring was continued overnight. Solvents were evaporated under reduced pressure (ca 1/3 vol.) and an oily residue was dissolved in chloroform, washed twice with $\mathrm{NaHCO}_{3}(0.1$ $\mathrm{M}$ ), and water. The organic layer containing 8 was dried with $\mathrm{MgSO}_{4}$, concentrated to dryness and coevaporated twice with toluene. This crude reaction mixture was dissolved in small volume of dry THF and treated with $\mathrm{Et}_{3} \mathrm{~N} \cdot 3 \mathrm{HF} / \mathrm{Et}_{3} \mathrm{~N}(3: 1 \mathrm{v} / \mathrm{v})$. After deprotection was complete $(3-4 \mathrm{~h})$, the reaction mixture was diluted with chloroform, washed twice with $\mathrm{NaHCO}_{3}(0.1 \mathrm{M})$, concentrated, and subjected to a silica gel column chromatography (gradient 0-6\% EtOH in chloroform, with addition of $0.05 \%$ of $\mathrm{Et}_{3} \mathrm{~N}$ ). The collected fractions of pure diastereomers 3 were concentrated, precipitated to hexane and stored as white powders. Total yield $61 \%$.

FAST- $\left(\mathbf{S}_{\mathbf{p}}\right)$-3. $\left(\mathrm{R}_{\mathrm{f}}=0.5, \mathrm{CHCl}_{3}\right.$-EtOH, 9:1), ${ }^{31} \mathrm{P} \mathrm{NMR}\left(202.46 \mathrm{MHz}, \mathrm{CDCl}_{3}\right) \delta: 100.1,{ }^{1} \mathrm{H} \mathrm{NMR}$ $\left(500 \mathrm{MHz}, \mathrm{CDCl}_{3}\right) \delta: 1.59\left(\mathrm{t},{ }^{3} J_{\mathrm{HH}}=7.59,6 \mathrm{H}, \mathrm{CH}\left(\mathrm{CH}_{3}\right)_{2}\right), 1.94\left(\mathrm{~d},{ }^{2} J_{\mathrm{PH}}=15.61,3 \mathrm{H}, \mathrm{P}-\mathrm{CH}_{3}\right), 2.1$ (dq, $\left.1 \mathrm{H}, \mathrm{C} \underline{\mathrm{H}}\left(\mathrm{CH}_{3}\right)_{2}\right), 2.56(\mathrm{~m}, 1 \mathrm{H}), 3.44(\mathrm{dd}, 1 \mathrm{H}), 3.6$ (s, 3H, (C)C $\underline{\mathrm{H}}_{3} \mathrm{O}-\mathrm{C} 2$ '), 3.74 (s, 3H, (Ura) $\underline{\mathrm{H}}_{3} \mathrm{O}-$ C2'), 3.8 (s, 6H, (Ura)C $\left.\underline{H}_{3} \mathrm{O}-\mathrm{DMT}\right), 3.92(\mathrm{~m}, 1 \mathrm{H}), 4.18(\mathrm{dd}, 1 \mathrm{H}),, 4.26\left(\mathrm{~d},{ }^{3} J_{\mathrm{HH}}=6.56,1 \mathrm{H}\right.$, (Ura) $\left.\underline{\mathrm{H}} 2^{\prime}\right), 5.36$ (m, 1H, (C) $\left.\underline{\mathrm{H}} 2^{\prime}\right), 5.87$ (s, 1H, (C) $\left.\underline{\mathrm{H}} 1^{\prime}\right), 6.05$ (d, $\left.{ }^{3} J_{\mathrm{HH}}=3.41,1 \mathrm{H},(\mathrm{Ura}) \underline{\mathrm{H} 1}{ }^{\prime}\right)$; FAB'MS [M-H]: $962.6\left(\mathrm{C}_{46} \mathrm{H}_{55} \mathrm{~N}_{5} \mathrm{O}_{14} \mathrm{PS}\right.$ : calcd 963.99), $[\alpha]_{\mathrm{D}}=+50.7^{\circ}\left(\mathrm{c}=0.1, \mathrm{CHCl}_{3}\right)$.

SLOW-( $\left.\mathbf{R}_{\mathbf{p}}\right)$-3. $\left(\mathrm{R}_{\mathrm{f}}=0.45, \mathrm{CHCl}_{3}-\mathrm{EtOH}, 9: 1\right),{ }^{31} \mathrm{P} \mathrm{NMR}\left(\mathrm{CDCl}_{3}\right) \delta: 98.26,{ }^{1} \mathrm{H} \mathrm{NMR}\left(\mathrm{CDCl}_{3}\right) \delta: 1.59$ $\left(\mathrm{t},{ }^{3} J_{\mathrm{HH}}=7.59,6 \mathrm{H}, \mathrm{CH}\left(\mathrm{C}_{3}\right)_{2}\right), 1.76\left(\mathrm{~d},{ }^{2} J_{\mathrm{PH}}=15.32,3 \mathrm{H}, \mathrm{P}-\underline{\mathrm{CH}}_{3}\right), 2.1\left(\mathrm{dq}, 1 \mathrm{H}, \mathrm{C} \underline{\mathrm{H}}\left(\mathrm{CH}_{3}\right)_{2}\right), 2.56(\mathrm{~m}$, $1 \mathrm{H}), 3.44(\mathrm{dd}, 1 \mathrm{H}), 3.55\left(\mathrm{~s}, 3 \mathrm{H},(\mathrm{C}) \underline{\mathrm{H}}_{3} \mathrm{O}-\mathrm{C} 2\right.$ '), 3.74 (s, 3H, (Ura) $\underline{\mathrm{H}}_{3} \mathrm{O}-\mathrm{C} 2$ '), 3.81 (s, 6H, (Ura) $\left.\underline{H}_{3} \mathrm{O}-\mathrm{DMT}\right), 3.92(\mathrm{~m}, 1 \mathrm{H}), 4.18(\mathrm{dd}, 1 \mathrm{H}),, 4.26\left(\mathrm{~d},{ }^{3} J_{\mathrm{HH}}=6.56,1 \mathrm{H},(\mathrm{Ura}){ }^{\prime}{ }^{\prime} \mathrm{H}\right), 5.36(\mathrm{~m}, 1 \mathrm{H}$, (C) $\left.\underline{\mathrm{H} 2}{ }^{\prime}\right), 5.95(\mathrm{~s}, 1 \mathrm{H},(\mathrm{C}) \underline{\mathrm{H} 1}), 6.02\left(\mathrm{~d},{ }^{3} J_{\mathrm{HH}}=3.43,1 \mathrm{H},(\mathrm{Ura}) \underline{\mathrm{H} 1}\right), 7.42\left(\mathrm{~d},{ }^{3} J_{\mathrm{HH}}=7.4,1 \mathrm{H},(\mathrm{C}) 5 \mathrm{H}\right)$, $7.92\left(\mathrm{~d},{ }^{3} J_{\mathrm{HH}}=8.2,1 \mathrm{H},(\mathrm{Ura}) 6 \mathrm{H}\right), 8.16\left(\mathrm{~d},{ }^{3} J_{\mathrm{HH}}=7.5,1 \mathrm{H},(\mathrm{C}) 6 \underline{\mathrm{H}}\right)$, FAB${ }^{-M S}[\mathrm{M}-\mathrm{H}]: 962.4$ (calcd 963.99). $[\alpha]_{\mathrm{D}}=81.9^{\circ}\left(\mathrm{c}=0.13, \mathrm{CHCl}_{3}\right)$

Removal of the 5'-O-DMT protecting group. Diastereomerically pure isomers 3 (20 mg) were separately dissolved in $2 \%$ dichloroacetic acid in $\mathrm{CH}_{2} \mathrm{Cl}_{2}(2 \mathrm{~mL})$ and stirred for $10 \mathrm{~min}$ at room temperature. After extraction (twice with sat. $\mathrm{NaHCO}_{3}$ ) each was purified by a flash silica gel column chromatography $\left(0-10 \% \mathrm{MeOH}\right.$ in $\left.\mathrm{CHCl}_{3}\right)$, and subjected to crystallization.

SLOW-4. $\left(\mathrm{R}_{\mathrm{f}}=0.3, \mathrm{CHCl}_{3}\right.$-EtOH, 9:1), ${ }^{31} \mathrm{P} \mathrm{NMR}\left(\mathrm{CDCl}_{3}\right) \delta: 98.44 ;{ }^{1} \mathrm{H} \mathrm{NMR}\left(\mathrm{CDCl}_{3}\right) \delta: 1.97$ (d, $\left.{ }^{2} J_{\mathrm{PH}}=15.50,3 \mathrm{H}, \mathrm{P}-\underline{\mathrm{H}}_{3}\right), 5.77\left(\mathrm{~d},{ }^{3} J_{\mathrm{HH}}=4.20 \mathrm{~Hz}, 1 \mathrm{H},(\mathrm{C}) \underline{\mathrm{H} 1}\right.$ ), $5.92\left(\mathrm{~d},{ }^{3} J_{\mathrm{HH}}=0.76,1 \mathrm{H},(\mathrm{Ura}) \underline{\mathrm{H}} 1^{\prime}\right)$; $\mathrm{C}_{25} \mathrm{H}_{36} \mathrm{~N}_{5} \mathrm{O}_{12} \mathrm{PS}, \mathrm{FW}=661.62, \mathrm{FAB}$ MS. FAB $[\mathrm{M}-\mathrm{H}]: 660.3, \mathrm{FAB}^{+}[\mathrm{M}+\mathrm{H}]: 662.2$.

FAST-4. $\left(\mathrm{R}_{\mathrm{f}}=0.32, \mathrm{CHCl}_{3}\right.$-EtOH, 9:1) ${ }^{31} \mathrm{P} \mathrm{NMR}\left(\mathrm{CDCl}_{3}\right) \delta: 98.54 ;{ }^{1} \mathrm{H} \mathrm{NMR}\left(\mathrm{CDCl}_{3}\right) \delta: 1.98(\mathrm{~d}$, $\left.{ }^{2} J_{\mathrm{PH}}=15.89,3 \mathrm{H}, \mathrm{P}-\underline{\mathrm{H}}_{3}\right), 5.69\left(\mathrm{~d},{ }^{3} J_{\mathrm{HH}}=5.17,1 \mathrm{H},(\mathrm{C}) \underline{\mathrm{H} 1}\right), 5.92\left(\mathrm{~d},{ }^{3} J_{\mathrm{HH}}=0.77,1 \mathrm{H},(\mathrm{Ura}) \underline{\mathrm{H} 1}{ }^{\prime}\right) ; \mathrm{FAB}$ MS. FAB $[\mathrm{M}-\mathrm{H}]$ : 660.3. Isomer SLOW-4, obtained from SLOW-3, was crystallized from 95\% ethanol at room temp, providing crystals suitable for $\mathrm{X}$ ray analysis.

\section{X - Ray analysis}

Crystal and molecular structure of SLOW-4 was determined on a CAD4 diffractometer with graphite monochromatized $\operatorname{CuK} \alpha(\lambda=1.541 \AA)$ radiation up to a resolution of $(\sin \theta / \lambda)_{\max }=0.6268$ $\AA^{-1}$. The crystal structure was solved by a conventional direct method using the SHELXL program package, followed by the least squares structural refinement and calculated difference density. Compound SLOW-4 crystallized in orthorhombic system in space group P $2{ }_{1} 2_{1} 2_{1}$ with 
the unit cell consisting of four molecules, without molecules of solvent(s) used for crystallization. An empirical absorption correction was applied by the use of the $\psi$-scan method. ${ }^{34}$ The structure was solved by the direct methods with total of 6010 reflections with $\mathrm{I}>0 \sigma(\mathrm{I})$ used and refined by the full matrix least squares using $\mathrm{F}^{2}$. Hydrogen atoms were located in the difference Fourier map, and refined isotropically, excepting hydrogen atoms at the $\mathrm{C}_{2}$ 'b and $\mathrm{C}_{5}{ }^{\prime} \mathrm{b}$ carbons. The latter were placed geometrically at idealized positions and set as riding with $\mathrm{U}_{\text {iso }}$ and $\mathrm{C}-\mathrm{H}$ distances free to refine with rotation about the $\mathrm{O}_{2}{ }^{\prime} \mathrm{b}-\mathrm{C}_{2}{ }^{\prime} \mathrm{b}$ bond allowed. Anisotropic thermal parameters were applied for all non-hydrogen atoms. The final refinement converged to $\mathrm{R}=0.0469$ for 5304 reflections, with $\mathrm{I}>2 \sigma(\mathrm{I})$.

\section{Acknowledgments}

This project was financially assisted by the State Committee for Scientific Research (Grant 4 TO9A 07325 for LAW), and in part, by Genta Co., USA.

Crystallographic data (excluding structure factors) for SLOW-4, have been deposited with the Cambridge Crystallographic Data Centre as supplementary publication numbers CCDC 202479 Copies of these data, can be obtained, free of charge, on application to CCDC, 12 Union Road, Cambridge CB2 1EZ, UK (Fax: +44(0)-1223-336033 or e-mail:deposit@ccdc.cam.ac.uk)

\section{References}

1. Reynolds, M. A.; Hogrefe, R. I.; Jaeger, J. A.; Schwartz, D. A.; Riley, T. A.; Marvin, W. B.; Daily, W. J.; Vaghefi, M. M.; Beck, T. A.; Knowles, S. K.; Klem, R.E.; Arnold, L. J. Jr. Nucleic Acids Res. 1996, 24, 4584.

2. Miller, P. S.; Hamma, T. Antisense \& Nucl. Acids Drug Dev. 1999, 9, 367.

3. (a) Lloyd, B. H.; Giles, R. V.; Spiller, D. V.; Grzybowski, J.; Tidd, D. M.; Sibson, D. R. Nucleic Acids Res. 2001, 29, 3664. (b) Giles, R. V.; Spiller, D.V.; Grzybowski, J.; Clark, R. E.; Nicklin, P.; Tidd, D. M. Nucleic Acids Res. 1998, 26, 1567, and references therein.

4. See review: Wozniak, L. A. Rev. Heter. Chem. 1999, 19, 173.

5. Wozniak, L. A.; Okruszek, A. Chem. Soc. Rev. 3 2003, 158-169. Stec, W. J., Wozniak, L. A., Pyzowski, J.; Niewiarowski, W. Antisense Nucleic Acid Drug Dev. 1997, 7, 383.

6. Wozniak, L. A.; Janicka, M.; Stec, W. J. In preparation.

7. Annotation SLOW and FAST corresponds to the relative order of elution of diastereomers 3 and $\mathbf{4}$ from a silica gel column in chloroform/ethanol as eluting solvent.

8. Chacko, K. K.; Lindner, K.; Saenger, W.; Miller, P. S. Nucleic Acids Res. 1983, 11, 2801.

9. Han, F.; Watt, W.; Duchamp, D.; Callahan, L.; Kezdy, F. J.; Agarwal, K. Nucleic Acids Res. 1990, 18, 3921. 
10. Szabo, T.; Noreus, D.; Norrestam, R.; Stawinski, J. Nucleic Acids Res. 1993, 21, 3921.

11. Engels, J.; Jäger, A. Angew. Chem. Int. Ed. 1982, 94, 931.

12. Schweitzer, M. J.; Engels, J. W. J.Biomol Str.\& Dynam. 1999, 16, 1177, and references herein.

13. Boyle, A. L., Ed.; Current Protocols in Nucleic Acids Chemistry; John Wiley \& Sons: New York, 2000; Chap. 3.

14. (a) Wijkmans, J. C. H. M.; Ottenheim, W.; Kyul-Yeheskiely, E.; van der Marel, G. A.; Bloemhoff, W.; van Boom, J. H. Synthesis 1995, 97. (b) Marugg, J. E.; de Vroom, E.; Dreef, C. E.; Tromp, M.; van der Marel, G. A.; van Boom J. H. Nucleic Acids Res. 1986, 14, 2171.

15. Milecki, J.; Dembek, P.; Antkowiak, W. Z.; Gdaniec, Z.; Mielewczyk, S.; Adamiak, R. Nucleosides \& Nucleotides 1989, 8, 463.

16. Garregg, P. J.; Regberg, T.; Stawinski, J.; Strömberg, R. Chem. Scr. 1985, 25, 280.

17. Wada, T.; Sato, Y.; Honda, F.; Kawahara, S.; Sekine, M. J. Am. Chem. Soc. 1997, 119, 12710, and ref. herein.

18. Mikkola, S.; Stenman, E.; Nurmi, K.; Yousefi-Sakdeh, E.; Stromberg, R.; Lonnberg, H. J. Chem. Soc., Perkin 2 1999, 1619.

19. Wada, T.; Kato, R.; Hata, T. J. Org. Chem. 1991, 56, 1243 and ref. herein.

20. Blackburn, G. M.; Guo, M.-J. Tetrahedron Lett. 1993, 34, 149.

21. Porrit, G. M.; Reese, C. B. Tetrahedron Lett. 1990, 31, 1319.

22. Brill, W. K- D.; Yu, E. K.; Caruthers, M. H. Tetrahedron Lett. 1989, 30, 6621.

23. Fourrey, J. L.; Varrenne, J. Tetrahedron Lett. 1985, 26, 2663.

24. (a) El-Abadla, N.; Lampilas, M.; Hennig, L.; Findeisen, M.; Wenzel, P.; Muller, D.; Markus, A.; von Heijnenoort, J. Tetrahedron, 1999, 55, 699. (b) Heuer, M.; Hohgardt, K.; Heineman, F.; Kuhne, H.; Dietrich, W.; Grzelak, D.; Wenzel, P.; Muller, P.; Markus, A.; von Heijenoort, Y.; von Heijenoort, J. Tetrahedron 1994, 50, 2029.

25. Loschner, T.; Engels, J. Tetrahedron Lett. 1989, 30, 5587.

26. Flack, H.D. Acta Cryst. 1983, A39, 876.

27. Neidle, S., Ed.; Oxford Handbook of Nucleic Acid Structure; Oxford Science Publ: Oxford, 1999.

28. Lubini, P.; Zurcher, W.; Egli, M. Chemistry \& Biology 1994, 1, 39.

29. Teresko, V.; Portman, S.; Tay, E. C.; Martin, P.; Natt, F.; Altmann, K. H.; Egli, M. Biochemistry 1998, 37, 10626.

30. Adamiak, D.; Milecki, J.; Popenda, M.; Adamiak, R. W.; Dauter, Z.; Rypniewski, W. R. Nucleic Acids Res. 1997, 25, 4599.

31. Saenger, W.; Principle of Nucleic Acid Structure; Springer Advanced Texts in Chemistry; Springer-Verlag : New York, 1984.

32. Chandrasekaran, R.; Arnott, S. J. Biomol. Struct. Dynamics 1996, 13, 1015.

33. Stec, W. J.; Karwowski, B.; Boczkowska, M.; Guga, P.; Koziołkiewicz, M.; Sochacki, M.; Wieczorek, M.W.; Błaszczyk, J. J. Am. Chem. Soc. 1998, 120, 7156.

34. Frenz, B. A.; Enraf-Nonius Structure Determination Package; SDP User's guide. EnrafNonius: Delft, Netherlands, 1986. 